\title{
Determination of genome size and a preliminary physical map of an extreme alkaliphile, Micrococcus sp. Y-1, by pulsed-field gel electrophoresis
}

\author{
Jong Hoon Park, ${ }^{1}$ Jae-Chan Song, ${ }^{2}$ Myoung Hee Kim ${ }^{1}$, Dae-Sil Lee ${ }^{2}$ \\ and Cheorl-Ho Kim ${ }^{2}$
}

Author for correspondence: Cheorl-Ho Kim. Tel: +82428604133. Fax: +82428604593.

Genome Program ${ }^{1}$ and Laboratory of Molecular and Cellular Biology, ${ }^{2}$ Genetic Engineering Research Institute, KIST, Taejon, Korea

\begin{abstract}
Large restriction fragments of genomic DNA from Micrococcus sp. Y-1 were separated by pulsed-field gel electrophoresis (PFGE). Since Micrococcus Sp. Y-1 has a $\mathbf{G}+C$ content of approximately $70 \%$, restriction fragments were obtained by digesting chromosomal DNA with endonucleases which recognize $\mathrm{A}$ - T-rich sequences. Five enzymes, Sspl, Spel, Xbal, Hpal and EcoRI, were used for generation of distinctly separated fragments in the size range 100-500 kb. No site for Dral was detected. In contrast, sites for 8-base-recognizing enzymes, but not for Notl and Sfil, were frequent. The genome size of Micrococcus sp. Y-1 was determined from restriction fragments separated by PFGE, and was estimated to be approximately $4061 \mathrm{~kb}$. Partial digestion experiments revealed the order of the six Sspl fragments on the chromosome.
\end{abstract}

Keywords: Micrococcus sp., alkaliphile, genome size

\section{INTRODUCTION}

Micrococcus sp. Y-1, a producer of alkaline pullulanase, is an extreme alkaliphile, growing at $\mathrm{pH}$ values from $6 \cdot 0$ to $12 \cdot 0$ and secreting amylolytic and pullulanolytic enzymes (Kim et al., 1993a). The discovery of Micrococcus sp. Y-1 has permitted a detailed study of the enzymes of an alkaliphilic bacterium (Kim et al., 1993a).

The alkaliphilic bacteria have been classified into three categories: (1) hyper-alkaliphiles, (2) extreme alkaliphiles and (3) moderate alkaliphiles. Extremely alkaliphilic bacteria of the genus Micrococcus grow over the $\mathrm{pH}$ range $8 \cdot 0 \cdot 12 \cdot 0$ (Kim et al., 1993a).

Most bacterial genomes comprise one circular chromosome (Smith et al., 1987). Two exceptions have been reported. One is Rhodobacter sphaeroides, which has two unique circular chromosomes of different sizes (Suwanto \& Kaplan, 1989). The other exceptions are members of the genus Borrelia, such as B. burgdorferi, which appear to have a linear chromosome (Baril et al., 1989; Ferdows \& Barbour, 1989).

Genomic mapping can be performed by physical mapping or by genetic linkage mapping. Physical mapping by

Abbreviation: PFGE, pulsed-field gel electrophoresis.
PFGE of large fragments of DNA generated using infrequently cutting restriction endonucleases has made it possible to map megabase regions of eukaryotes and whole genomes of prokaryotes (Schwartz et al., 1983; Renaud et al., 1988; Bancroft et al., 1989). Approximately 40 bacterial genome maps (Krawiec \& Riley, 1990) have been constructed by this method. These maps provide poor physical resolution, so their utility has been primarily to demonstrate mapping strategy and to confirm existing genetic maps (Smith et al., 1987). The aim of this work was to produce a preliminary physical map and to estimate the genome size of the extremely alkaliphilic bacterium Micrococcus sp. Y-1 using PFGE.

\section{METHODS}

Bacterial strain and culture. Micrococcus sp. Y-1 cells (Kim et al., 1993a) were grown at $50{ }^{\circ} \mathrm{C}$ for $16 \mathrm{~h}$ in medium ( $\mathrm{pH} \mathrm{7.2)}$ consisting of $0.8 \%$ polypeptone, $0.2 \%$ yeast extract and a basal salts mixture, as described by Kim et al. (1993b). Chloramphenicol $\left(100 \mathrm{mg} \mathrm{ml}^{-1}\right.$ in $95 \%, \mathrm{v} / \mathrm{v}$, ethanol) was added to a final concentration of $180 \mu \mathrm{g} \mathrm{ml}^{-1}$ and cells grown for a further $4 \mathrm{~h}$.

Preparation of bacterial plugs. Agarose plugs containing genomic DNA were prepared following the procedure of Bancroft et al. (1989). In brief, cells grown to late-exponential or stationary phase were pelleted by centrifugation at 3500 r.p.m. 
for $10 \mathrm{~min}$ at $4{ }^{\circ} \mathrm{C}$ in a clinical centrifuge. Cells were then washed by resuspension in $10 \mathrm{ml}$ buffer $(10 \mathrm{mM}$ Tris $/ \mathrm{HCl}, 1 \mathrm{M}$ $\mathrm{NaCl}, \mathrm{pH} \mathrm{7.6)}$, followed by centrifugation. After resuspension of the cells in $2 \mathrm{ml}$ suspension buffer $(0.01 \mathrm{M}$ Tris $/ \mathrm{HCl}, \mathrm{pH} 8.0$, $0 \cdot 1 \mathrm{M} \mathrm{Na}-E D T A, 0.02 \mathrm{M} \mathrm{NaCl}$ ), the suspension was warmed in an incubator at $30-40^{\circ} \mathrm{C}$, then diluted with an equal volume of $1 \%(\mathrm{w} / \mathrm{v})$ low-melting-temperature agarose (FMC BioProducts) made up in sterile water at $42^{\circ} \mathrm{C}$. The resulting solution was then poured into a mould chamber (Bio-Rad). Solidified blocks were incubated at $37^{\circ} \mathrm{C}$ for $12 \mathrm{~h}$ in lysozyme (Sigma) solution $\left[1 \mathrm{mg} \mathrm{ml}^{-1}\right.$ in TE buffer $(10 \mathrm{mM}$ Tris/ $\mathrm{HCl}$, $1 \mathrm{mM}$ EDTA, pH 8.0)] then treated overnight at $50^{\circ} \mathrm{C}$ with an equal volume of buffer containing proteinase $\mathrm{K}\left(1 \mathrm{mg} \mathrm{ml}^{-1}\right.$; Boehringer Mannheim), 0.5\% N-lauroylsarcosine (Sigma) and $1 \mathrm{mM}$ EDTA, $\mathrm{pH} 8 \cdot 0$. Proteinase activity was inhibited by washing the blocks twice for $1 \mathrm{~h}$ at room temperature in phenylmethylsulphonyl fluoride $\left(40 \mu \mathrm{g} \mathrm{ml}^{-1} ; \mathrm{PMSF}\right)$. The blocks were then stored in $0.05 \mathrm{M} \mathrm{Na}$-EDTA $(\mathrm{pH} 8.0)$ at $4{ }^{\circ} \mathrm{C}$.

Restriction enzyme digestion of DNA using agarose blocks and PFGE. Agarose blocks containing $1 \mu \mathrm{g}$ micrococcal DNA were subjected to single or double digestion with restriction endonucleases. DNA was digested for $20 \mathrm{~h}$ at $37^{\circ} \mathrm{C}$ in $0.1 \mathrm{ml}$ restriction endonuclease buffer containing $0.01 \%$ bovine serum albumin. For total digestion of DNA, $10 \mathrm{U}$ restriction endonuclease $S_{s p \mathrm{I}}$ (Boehringer Mannheim) and $10 \mathrm{U}$ EcoRI (Promega) were used. For partial digestion with $S_{s} p \mathrm{I}, 5 \mathrm{U}$ were used. After digestion, blocks were equilibrated in TE buffer, then mounted on the teeth of an electrophoresis comb. The gel was cast with $1.0 \%(\mathrm{w} / \mathrm{v})$ SeaPlaque agarose (FMC) at $55^{\circ} \mathrm{C}$ in $0.5 \times$ TBE buffer $(10 \mathrm{mM}$ Tris/borate, $1 \mathrm{mM}$ EDTA). The gel was electrophoresed at $14{ }^{\circ} \mathrm{C}$ in a CHEF DR II apparatus (Bio$\mathrm{Rad})$. For separation of fragment sizes between 4 and $200 \mathrm{~kb}$, the gel was run for $20 \mathrm{~h}$ at $200 \mathrm{~V}$ with a ramped pulse time from 1 to $15 \mathrm{~s}$. The same time and voltage were used for separation of the size range $6-600 \mathrm{~kb}$, but the ramped pulse time was from 15 to $75 \mathrm{~s}$. Bacteriophage $\lambda$ DNA digested with HindIII (Promega) was used as size markers for DNA fragments smaller than $50 \mathrm{~kb}$, and Saccharomyces cerevisiae and Schizosaccharomyces pombe chromosomes (Bio-Rad) were used as size markers for high-molecularmass DNA fragments. After electrophoresis, gels were stained with $0.5 \times$ TBE containing ethidium bromide $\left(0.5 \mu \mathrm{g} \mathrm{ml}^{-1}\right)$ for $30 \mathrm{~min}$, then destained in distilled water.

\section{RESULTS AND DISCUSSION}

\section{Selection of suitable enzymes for PFGE analysis of Micrococcus sp. Y-1}

Micrococcus sp. Y-1 has a $\mathrm{G}+\mathrm{C}$ content of approximately $70 \%$ (Kim et al., 1993a). Sites for restriction enzymes that cleave at $\mathrm{A}+\mathrm{T}$-rich sequences are expected to be rare in the genome of Micrococcus sp. Y-1. Seven such enzymes, SspI (AATATT), SpeI (ACTAGT), HpaI (GTTAAC), Xbal (TCTAGA), NdeI (CATATG), Dral (TTTAAA) and EcoRI (GAATTC) were identified as suitable for generation of relatively few numbers of distinct fragments from the Micrococcus sp. Y-1 genome.

\section{Micrococcus sp. Y-1 genome size}

Chromosomal DNA of Micrococcus sp. Y-1 was digested and electrophoresed under migration conditions appropriate for resolving each restriction fragment. Pulse times were ramped from 5 to $25 \mathrm{~s}$ for $20 \mathrm{~h}$ at $200 \mathrm{~V}$ in order to resolve shorter fragments. High-molecular-mass fragments (up to $1000 \mathrm{~kb}$ ) were resolved using 15--75 s ramped pulse times for $20 \mathrm{~h}$ at $200 \mathrm{~V}$. Fig. 1 shows several patterns of restriction fragments separated by PFGE. The molecular size of PFGE-separated fragments for each enzyme was determined with respect to $\lambda$ concatamers and S. cerevisiae molecular mass standards (Table 1). To obtain good separation and size determination in the size range of the molecular mass standards, a ramped pulse time from $15 \mathrm{~s}$ to $75 \mathrm{~s}$ over $20 \mathrm{~h}$ was optimum. Separation of restriction fragments by PFGE allowed estimation of the molecular size of the Micrococcus sp. Y-1 genome.

Genome size was determined by adding the sizes of the restriction fragments obtained using several enzymes and resolved by PFGE. The genome size determined from each enzymic digestion is given in Table 1 . The average size of the intact chromosome of Micrococcus sp. Y-1 was approximately $4061 \mathrm{~kb}$ (Table 1).

The chromosomal restriction pattern for EcoRI involved 17 restriction fragments ranging in size from 730 to $30 \mathrm{~kb}$ (Table 1). Double digestion with SspI and SpeI resulted in 14 large fragments which were resolved by electrophoresis

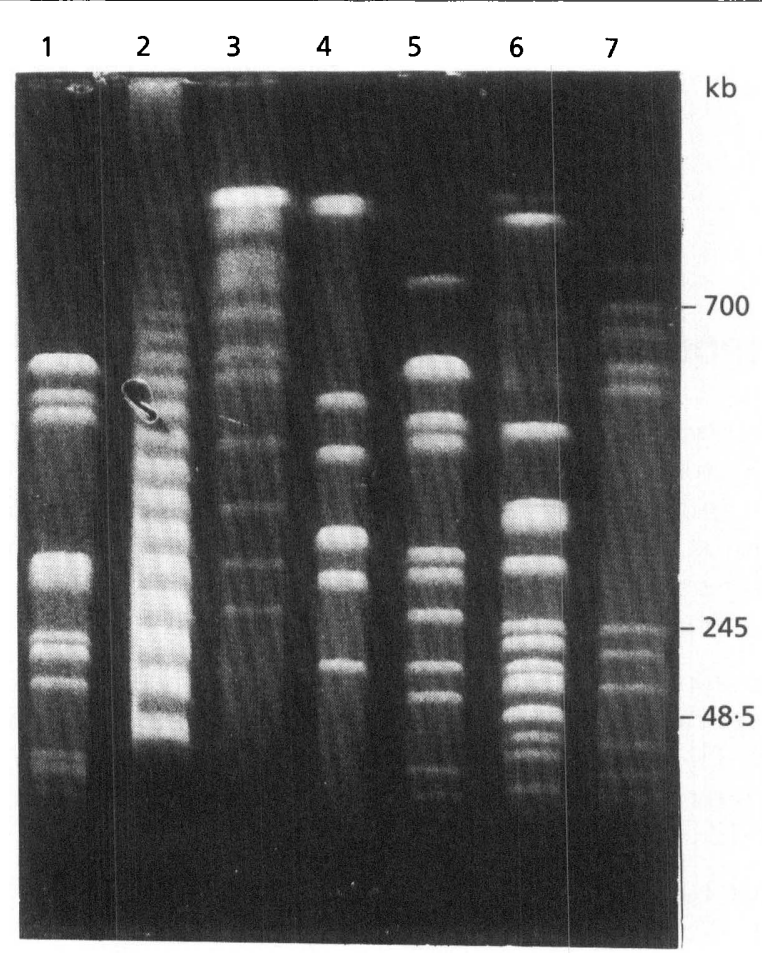

Fig. 1. PFGE of restriction endonuclease digests (Sspl, Spel, Xbal and Hpal) of Micrococcus sp. Y-1 genomic DNA. Lanes: 1 , Micrococcus sp. Y-1 genomic DNA digested with Sspl and Spel; 2, $\lambda$-DNA concatamer; 3, DNA size standard of $S$. cerevisiae chromosomal DNA; 4, Micrococcus sp. Y-1 genomic DNA digested with Sspl; 5, Micrococcus sp. Y-1 genomic DNA digested with Spel; 6, Micrococcus sp. Y-1 genomic DNA digested with Xbal; 7, Micrococcus sp. Y-1 genomic DNA digested with Hpal. The numbers on the right show the positions for the DNA size standard markers. The ramped pulse times were $15-75 \mathrm{~s}$ for $20 \mathrm{~h}$ at $14{ }^{\circ} \mathrm{C}$ and $200 \mathrm{~V}$. The gels were $1.0 \%$ SeaPlaque agarose in $0.1 \times$ TBE. 
Table 1. Sizes of the chromosomal Sspl, Spel, Xbal, Hpal and EcoRI restriction fragments from Micrococcus sp. Y-1

\begin{tabular}{|c|c|c|c|c|c|c|c|c|c|}
\hline SspI & $\begin{array}{l}\text { Length } \\
\text { (kb) }\end{array}$ & SpeI & $\begin{array}{c}\text { Length } \\
\text { (kb) }\end{array}$ & XbaI & $\begin{array}{c}\text { Length } \\
(\mathrm{kb})\end{array}$ & HpaI & $\begin{array}{c}\text { Length } \\
\text { (kb) }\end{array}$ & EcoRI & $\begin{array}{c}\text { Length } \\
(\mathbf{k b})\end{array}$ \\
\hline$S s-1$ & 2280 & $S_{p-1}$ & 760 & $\mathrm{Xb}-1$ & 960 & Hp-1 & 800 & Ec-1 & 730 \\
\hline Ss-2 & 580 & $S p-2 a$ & 560 & $\mathrm{Xb}-2$ & 470 & $\mathrm{Hp}-2$ & 720 & Ec-2 & 710 \\
\hline Ss -3 & 460 & $2 \mathrm{~b}$ & 560 & $\mathrm{Xb}-3$ & 370 & $\mathrm{Hp}-3$ & 660 & Ec-3 & 620 \\
\hline Ss -4 & 330 & Sp-3 & 520 & $\mathrm{Xb}-4 \mathrm{a}$ & 348 & $\mathrm{Hp}-4$ & 580 & Ec-4 & 372 \\
\hline Ss -5 & 280 & $S p-4$ & 470 & $4 b$ & 348 & $\mathrm{Hp}-5$ & 540 & Ec-5 & 360 \\
\hline \multirow[t]{12}{*}{ Ss-6 } & 108 & $S p-5$ & 345 & $4 c$ & 348 & $\mathrm{Hp}-6$ & 240 & Ec-6 & 280 \\
\hline & & $\mathrm{Sp}-6$ & 320 & Xb-5 & 302 & $\mathrm{Hp}-7$ & 220 & Ec-7 & 260 \\
\hline & & Sp-7 & 260 & $\mathrm{Xb}-6$ & 240 & $\mathrm{Hp}-8$ & 170 & Ec-8 & 180 \\
\hline & & Sp-8 & 180 & $\mathrm{Xb}-7$ & 150 & Hp-9 & 53 & Ec-9 & 127 \\
\hline & & Sp-9 & 120 & $\mathrm{Xb}-8$ & 109 & $\mathrm{Hp}-10$ & 42 & Ec-10 & 100 \\
\hline & & $S_{p}-10$ & 45 & $\mathrm{Xb}-9$ & 97 & Hp-11 & 34 & Ec-11 & 80 \\
\hline & & Sp-11 & 34 & Xb-10 & 68 & $\mathrm{Hp}-12$ & 30 & Ec-12 & 60 \\
\hline & & & & Xb-11 & 48 & & & Ec-13 & 48 \\
\hline & & & & $\mathrm{Xb}-12$ & 43 & & & Ec-14 & 43 \\
\hline & & & & $\mathrm{Xb}-13$ & 26 & & & Ec-15 & 40 \\
\hline & & & & & & & & Ec-16 & 35 \\
\hline & & & & & & & & Ec-17 & 30 \\
\hline Total & 4038 & & 4174 & & 3927 & & 4089 & & 4075 \\
\hline Average & size: 406 & & & & & & & & \\
\hline
\end{tabular}

Table 2. Size of the chromosomal partial Sspl restriction fragments from Micrococcus sp. Y-1

\begin{tabular}{|ccc|}
\hline Size (kb) & Possible combination & $\begin{array}{c}\text { Total size of } \\
\text { fragments (kb) }\end{array}$ \\
\hline 2910 & Ss-1+Ss-2 & 2860 \\
920 & Ss-2+Ss-4 & 910 \\
820 & Ss-3+Ss-5 + Ss-6 & 848 \\
680 & Ss-4 + Ss-5+Ss-6 & 718 \\
530 & Ss-3+Ss-6 & 568 \\
400 & Ss-5 + Ss-6 & 388 \\
\hline
\end{tabular}

(Fig. 1, lane 1) and four small fragments not shown. For further separation of small size bands, a pulsed ramp time from 5 to $25 \mathrm{~s}$ over $20 \mathrm{~h}$ was optimum (data not shown). Dral treatment produced no fragments, while the 8-baserecognizing restriction enzymes NotI (GCGGCCGC) and Sfil (GGCCN5GGCC) cut the genomic DNA into many fragments which were too small and numerous for genome sizing (data not shown).

Analysis of bacterial chromosomes using frequent-cutting restriction enzymes has been reported (Krawiec \& Riley, 1990). However, the large number of chromosomal fragments generated by these enzymes produce complicated banding patterns which are difficult to resolve and compare. Even though high resolution restriction fragment fingerprints of bacterial chromosomes can be produced with frequent-cutting restriction enzymes using two-dimensional electrophoresis, comparison with multiple enzyme fragmentation cannot be done in one experiment (Poddar \& Maniloff, 1989). The PFGEdetermined molecular sizes of several bacterial genomes, such as Escherichia coli (Smith et al., 1987), Mycoplasma mycoides (Pyle \& Finch, 1988), Haemophilus influenzae (Kauc et al., 1989) and Pseudomonas aeruginosa (Hector \& Johnson, 1990) have been reported. In this study, the genome size of Micrococcus sp. Y-1 was estimated using PFGE. Although the contribution of any single plasmid to the estimation of genome size is insignificant, PFGE experiments using a $15 \mathrm{~s}$ pulse time for $14 \mathrm{~h}$ with undigested genomic DNA showed no evidence of any plasmid in the strain (data not shown).

\section{Physical map of the Micrococcus sp. Y-1 genome}

Digestion of chromosomal DNA with $S_{s p I}$ resulted in six restriction fragments ranging in size from 2280 to $108 \mathrm{~kb}$ (Table 1). Partial digestion experiments suggested that the partial fragments of $2910 \mathrm{~kb}, 920 \mathrm{~kb}, 820 \mathrm{~kb}, 680 \mathrm{~kb}$, $530 \mathrm{~kb}$ and $400 \mathrm{~kb}$ were combinations of the fragments from completely digested DNA (Table 2). The Ss-2 fragment ( $580 \mathrm{~kb}$; Table 1 ) was also detected after double digestion with $S_{s p \mathrm{I}}$ and $S p e \mathrm{I}$, while the Ss-1 $(2280 \mathrm{~kb})$ and Sp-1 (760 kb) fragments were not (Fig. 1, lane 1).

A complete $S$ spI restriction map of the Micrococcus sp. Y-1 chromosome was obtained. The six $S s p$ I bands formed a circle, demonstrating the circular topology of the chromosome (Fig. 2). Use of SpeI, XbaI, HpaI and EcoRI will allow development of a high density map of the 


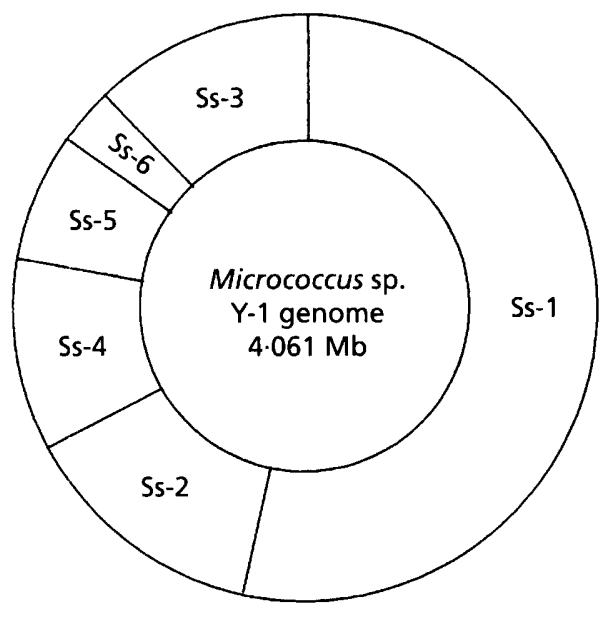

Fig. 2. Physical map of the Micrococcus sp. Y-1 genome. The six Sspl bands are aligned in the inner circle and are listed in Table 1.

circular chromosome. If, in the future, Micrococcus sp. Y-1 genes are cloned, hybridization methods can be used to confirm the physical map of this genome. This work constitutes, to our knowledge, the first estimation of the genome size of an alkaliphilic Micrococcus sp.

\section{ACKNOWLEDGEMENTS}

We thank Professor D. T. Cassell, HNU, Taejon, Korea, for critical reading of the manuscript. This work was supported by a grant for the 1992 genome program to Dr C.-H. Kim from the Ministry of Science and Technology (MOST), Korea.

\section{REFERENCES}

Bancroft, I., Wolk, C. P. \& Oren, E. V. (1989). Physical and genetic map of the genome of the heterocyte-forming cyanobacterium Anabaena sp. strain PCC7120, J Bacteriol 171, 5940-5948.
Baril, C. C., Richaud, G. B. \& Saint Girons, I. S. (1989). Linear chromosome of Borrelia burgdorferi. Res Microbiol 140, 507-516.

Ferdows, M. S. \& Barbour, A. G. (1989). Megabase-sized linear DNA in the bacterium Borrelia burgdorferi, the Lyme disease agent. Proc Natl Acad Sci US A 86, 5969-5973.

Hector, J. S. R. \& Johnson, A. R. (1990). Determination of genome sizes of Pseudomonas aeruginosa by PFGE: analysis of restriction fragments. Nucleic Acids Res 18, 3171-3174.

Kauc, L., Mitcheu, M. \& Goodgal, S. H. (1989). Size and physical map of the chromosome of Haemopbilus infuenzae. J Bacteriol 171, 2474-2479.

Kim, C. H., Choi, H. I. \& Lee, D.-S. (1993a). Pullulanases of alkaline and broad $\mathrm{pH}$ range from a newly isolated alkalophilic Bacillus sp. S-1 and a Micrococcus sp. Y-1. I Ind Microbiol 12, 48-57.

Kim, C. H., Choi, H. I. \& Lee, D.-S. (1993b). Purification and biochemical properties of an alkaline pullulanase from alkalophilic Bacillus sp. S-1. Biosci Biotechnol Biochem 57, 1632-1637.

Krawiec, S. \& Riley, M. (1990). Organization of the bacterial chromosome. Microbiol Rev 54, 502-539.

Poddar, S. K. \& Maniloff, J. (1989). Determination of microbial genome sizes by two dimensional denaturing gradient gel electrophoresis. Nucleic Acids Res 17, 2889-2898.

Pyle, L. E. \& Finch, L. R. (1988). Preparation and FIGE separation of infrequent restriction fragments from Mycoplasma mycoides DNA. Nucleic Acids Res 25, 2263-2268.

Renaud, F., Freny, J., Etienne, J., Bes, M., Brun, Y., Brasotti, O., Andre, S. \& Fleurette, J. (1988). Restriction endonuclease analysis of Staphylococcus epidermidis DNA may be a useful epidermiological marker. J Clin Microbiol 26, 1729-1734.

Schwartz, D. C., Saffran, W., Welsh, J., Haas, R., Goldenberg, M. \& Cantor, C. R. (1983). New techniques for purifying large DNAs and studying their properties and packaging. Cold Spring Harbor Symp Quant Biol 47, 189-195.

Smith, C. L., Econome, J., Schutt, A., KIco, S. \& Cantor, C. R. (1987). A physical map of the Escherichia coli K-12 genome. Science 236, 1448-1453.

Suwanto, A. \& Kaplan, S. (1989). Physical and genetic mapping of the Rbodobacter sphaeroides 2.4 .1 genome: genome size, fragment identification, and gene localization. J Bacteriol 171, 5840-5849.

Received 9 November 1993; revised 8 April 1994; accepted 19 April 1994. 